\title{
Pupils' Perceptions of the Moral Atmosphere in Some Secondary Schools in Harare, Zimbabwe
}

\author{
T.D. Mushoriwa \\ University of Fort Hare
}

\section{Doi:10.5901/mjss.2014.v5n20p1596}

\begin{abstract}
The present study investigated pupils' perceptions of the moral atmosphere in their schools. Precisely the study aimed at exploring how pupils perceive the moral climate and moral standards in their schools and how these perceptions impact on their behaviour in and around the school. A survey questionnaire, supplemented by follow-up interviews, was conducted on 100 Form IV pupils randomly drawn from 2 Government Secondary Schools in Harare's high density suburbs. Overall, the study established that the majority of pupils are bitter about the negative moral atmosphere prevailing in schools. Many of the pupils called for the sanitisation of school environments if parents, pupils and other stakeholders are to continue having confidence in the schooling system. The study recommends that heads of schools and the Ministry of Education, Arts and Culture should ensure that the moral atmosphere in schools should be supportive of pupils' learning and should always remind pupils that they are in a place of learning. The way many pupils dress and conduct themselves need to be closely monitored.
\end{abstract}

Keywords: perceptions, moral atmosphere, social and academic behaviour

\section{Introduction}

The study of perceptions is critical because, perception, being the first step in processing information (Gielen, 1991; Rest, Narvaez, Bebeau \& Thoma, 1999) influences not only our initial impression of phenomena and issues, but also how we eventually view, judge and value those phenomena and issues (Rajecki, 1982). To this extent, the current study assumed that the moral atmosphere in schools influences pupils' social and academic behaviour in and around the school. For Brugman, Podolskij, Heymans, Boom, Karabanova \& Idobaeva (2003), how pupils and children in general perceive morality and moral standards in the school or home affects their norm-transgressive and pro-social behaviour. What goes on in the school or home greatly influences not only how pupils will morally and socially behave but also but also how seriously they will take their academic work.

The present study thus adopted an approach or model that links moral perception to behaviour. It was postulated that there is a causal link between perception of moral atmosphere in the school and the pupils' behaviour since perceptions have been found to influence the way people judge, interpret, act and react to issues (Mushoriwa, 2008).

\section{Definitions of Terms}

Moral Atmosphere: This term refers to the norms, beliefs, values and meaning systems that regulate social relationships within the school and to the degree to which these norms and values are shared by the students (Power, Higgins \& Kohlberg, 1989). For Brugman et al. (2003), it is this school moral atmosphere that enables students to share experiences concerning their school and class and to perceive and interpret systematically and in accordance with the majority perspective. Thus, ideally, the school as a community should have members who have common goals and a sense of shared purpose to which they all should, by definition, actively contribute and feel committed (Solomon, Watson, Battistich, Schaps and Delucchi, 1996). This shows that the school's moral atmosphere plays a critical role in determining how members of the school community view and relate to each other, to the school and its activities and how they (members) eventually behave.

\section{Background and Literature Review}

While the school environment's contributions to children's behaviour is of great concern to many people, disturbingly the link between the school's moral atmosphere and pupils' behaviour has been much less studied (Brugman et al. 2003). 
This paucity or in some cases, complete lack of research in this area, especially in developing countries such as Zimbabwe, is indeed myopic given that studies such as those by Host, Brugman, Tavecchio \& Beem (1998); Brugman et al. (2003) have established that the school's moral atmosphere affects students' behaviour, academic performance, career planning, academic attitudes, life attitudes, motives, social and personal attitudes. Thus, it is important that the school's moral atmosphere be explored since it directly contributes to pupils' socialisation, academic development and school career in general. Such a study is indeed applied in that it identifies the nature, origination and underpinnings of the subjects' perceptions in order to improve the atmosphere for the benefit of all members of the school community.

To the present writer's knowledge, while no research on the link between the school's moral atmosphere and pupils' behaviour has been conducted in Zimbabwe and thus creating a void in research, some research studies in this area have been conducted elsewhere. For example, Host et al. (1998) in the Netherlands found that raising the level of moral atmosphere in a school resulted in significant reductions in thefts by pupils. Kuther (2000) found in the United Kingdom, a link between moral competence and transgressions of moral norms. These studies found a link between moral atmosphere and behaviour, a thing which is assumed in the current study.

The present study was partly premised on the belief that due to the economic challenges Zimbabwe is currently facing, there could be disintegration of moral values in schools. For both teachers and pupils, life is not quite normal; many of them may be engaging in shady deals in order to make a living. Once there is little moral cohesion in a school, moral transgression is likely to be high. Such moral transgressions as stealing, prostitution for material benefits, bullying, smoking, lying, cheating, sexual abuse, dishonesty and so on may start taking root. These may consequently interfere with pupils' well-being and learning.

It is against such a background that the present study set out to explore pupils' perceptions of the moral atmosphere that prevails in some Zimbabwean secondary schools and how these perceptions impact on the pupils' behaviour.

\section{Objective of the Study}

As already noted, the objective of the study was to explore pupils' perceptions of the moral atmosphere prevailing in their schools with the ultimate aim of assessing the impact of the school's moral atmosphere on pupils' moral, social and academic behaviour in and around the school.

\section{Methodology}

\subsection{Research Design}

The survey research design was used in this study. Survey manipulations do not only have the advantage of being used on relatively large samples as was the case in this study $(n=100)$ but they also permit detailed descriptions of existing phenomena and/or trends with a view to either justifying them or improving current practices. To this effect, it was the intention of the current study to examine pupils' perceptions of the moral atmosphere existing in their school with a view to improving the moral atmosphere for the benefit of everyone involved.

\subsection{Sample}

One hundred ( $n=100)$ Form IV pupils (boys=50\%; mean age=14.2; $S D=0.3$ ) who were randomly selected from two secondary schools in Harare's high density suburbs, participated in this study. While the sample size $(\mathrm{N}=100)$ was not sufficiently representative of the total number of Form IV pupils in schools in Harare's high density suburbs mostly because of limitations imposed by expenses, it was representative in terms of pupil numbers in the two schools $(N=384)$ and in terms of the kind of those numbers since 50 male and 50 females pupils were involved.

For Van Dalen (1979), if it is Descriptive Research (which the current study was) anything from $10 \%$ to $20 \%$ of the target population is representative enough to warrant generalisation of results. One hundred pupils out of three hundred and eighty-four pupils is $26 \%$, which is more than what Van Dalen (1979) recommends. Hence, in this sense, the sample was representative. The involvement of two schools was also significant in that it facilitated a comparative analysis of the moral atmosphere prevailing in the two schools as perceived by pupils in those schools. 


\subsection{Instruments}

A modified form of the questionnaire originally developed by Host et al. (1998) and follow-up interviews were the instruments used in this study. Basically the questionnaire used two response formats (yes-no ratings and likert scaling) not only for controlling response bias, but also for ensuring appropriateness of format to the kind of information required. In most cases, participants were required to give reasons for their answers.

Follow-up interviews were used to probe in to subtle issues which the researcher felt could not be revealed through the questionnaire. A total of 40 pupils, randomly selected, were interviewed.

\subsubsection{Validity and Reliability of the Questionnaire}

Although the validity and reliability of the School Moral Atmosphere Questionnaire have been thoroughly investigated by researchers such as Host et al. (1998) and Brugman, Tavecchio, Van Os and Host (1999) and found to be acceptable, in the present study, it was felt necessary to test the suitability of the instrument again not only because the questionnaire was adopted with modifications but also because the participations and circumstances were different. Since an instrument cannot perform similarly across different studies and situations (Kelderman, 1986), there was therefore need to adapt it to the Zimbabwean context and then pilot-test it for relevance and suitability.

The questionnaire was first given to six experts in the field of perceptions to check for suitability (validity). The same experts were asked to rate (out of 20 ) the questionnaire. An inter-rater analysis yielded a sufficiently acceptable coefficient of 0,65 . The high rater agreement indicates that the questionnaire was highly reliable and therefore suitable.

The questionnaire was then pilot-tested with a group of 20 Form IV pupils and it worked as intended. It was then administered to the study sample since it was found suitable.

\section{Data Presentation and Analysis}

\subsection{Data Presentation}

Participants were required to tick an answer that went with their views and in most cases, they were asked to give reason(s) for their answer(s). Since the questionnaire used two response formats (yes-no ratings and likert scaling), the subjects' responses are presented in two tables according to the response formats. Items 1, 3, 6, 7, 9, 10, 11, 12, 13 and 15 used likert scaling while items $2,4,5,8,14$, and 16 used the yes-no format.

The 16 questionnaire items were taken to be rating scales and as such, they were analysed individually. In the analysis/discussion, items that required similar information were discussed together. In the case of items that used likert scaling, the neutral point (undecided) was not included for purposes of analysis in order to make the results directional (Fishbein, 1975).

Table 1 (a): Pupils' Responses to the School Moral Atmosphere Questionnaire; Likert Scaling Items, $(n=100)$.

\begin{tabular}{|c|c|c|c|c|c|c|c|c|c|}
\hline Item & \multicolumn{9}{|c|}{ Responses } \\
\hline & \multicolumn{3}{|c|}{ School A $(n=50)$} & \multicolumn{3}{|c|}{ School $B(N=50)$} & \multicolumn{3}{|c|}{ Total $(\mathrm{N}=100)$} \\
\hline \multirow[b]{2}{*}{$\begin{array}{l}\text { 1. The moral atmosphere in our school is - (Good (G); Poor }(P) \text {; } \\
\text { Undecided }(U)) \text {. }\end{array}$} & $\mathrm{G}$ & $P$ & U & G & $P$ & U & $\mathrm{G}$ & $P$ & U \\
\hline & $\begin{array}{c}24 \\
(48 \%)\end{array}$ & $\begin{array}{c}26 \\
(52 \%)\end{array}$ & $0(0 \%)$ & $\begin{array}{c}41 \\
(82 \%)\end{array}$ & $\begin{array}{c}8 \\
(16 \%)\end{array}$ & $\begin{array}{c}1 \\
(2 \%)\end{array}$ & $\begin{array}{c}65 \\
65 \%)\end{array}$ & $\begin{array}{c}34 \\
(34 \%)\end{array}$ & $1(1 \%)$ \\
\hline \multirow[b]{2}{*}{$\begin{array}{l}\text { 3. When at school, I feel - (Safe (S); Threatened (T); Undecided } \\
\text { (U)). }\end{array}$} & S & $\mathrm{T}$ & $\mathrm{U}$ & $\mathrm{S}$ & $\mathrm{T}$ & U & S & $\mathrm{T}$ & $\mathrm{U}$ \\
\hline & $\begin{array}{c}18 \\
(36 \%)\end{array}$ & $\begin{array}{c}21 \\
(42 \%)\end{array}$ & $\begin{array}{c}11 \\
(22 \%)\end{array}$ & $\begin{array}{c}39 \\
(78 \%)\end{array}$ & $\begin{array}{c}7 \\
(14 \%)\end{array}$ & $\begin{array}{c}4 \\
(8 \%)\end{array}$ & $\begin{array}{c}57 \\
(57 \%)\end{array}$ & $\begin{array}{c}28 \\
(28 \%)\end{array}$ & $\begin{array}{c}15 \\
(15 \%)\end{array}$ \\
\hline \multirow[b]{2}{*}{$\begin{array}{l}6 \text { I learn better moral values at - (Home }(H) \text {; School }(S) \text {; } \\
\text { Undecided }(U))\end{array}$} & $\mathrm{H}$ & $\mathrm{S}$ & U & $\mathrm{H}$ & S & U & $\mathrm{H}$ & S & U \\
\hline & $\begin{array}{c}27 \\
(54 \%)\end{array}$ & $\begin{array}{c}23 \\
(46 \%)\end{array}$ & $0(0 \%)$ & $\begin{array}{c}25 \\
(50 \%)\end{array}$ & $\begin{array}{c}25 \\
(50 \%)\end{array}$ & $\begin{array}{c}0 \\
(0 \%)\end{array}$ & $\begin{array}{c}52 \\
(52 \%)\end{array}$ & $\begin{array}{c}48 \\
(48 \%)\end{array}$ & $0(0 \%)$ \\
\hline \multirow{2}{*}{$\begin{array}{l}\text { 7. Most pupils in our school behave well - (Only in the presence } \\
\text { of teachers (PT); Even in the absence of teachers (AT); } \\
\text { Undecided (U)) }\end{array}$} & PT & AT & U & PT & AT & U & PT & AT & $\mathrm{U}$ \\
\hline & $\begin{array}{c}33 \\
(66 \%)\end{array}$ & $\begin{array}{c}16 \\
(22 \%)\end{array}$ & $1(2 \%)$ & $\begin{array}{c}22 \\
(44 \%)\end{array}$ & $\begin{array}{c}28 \\
(56 \%)\end{array}$ & $\begin{array}{c}0 \\
(0 \%)\end{array}$ & $\begin{array}{c}55 \\
(55 \%)\end{array}$ & $\begin{array}{c}44 \\
(44 \%)\end{array}$ & $1(1 \%)$ \\
\hline
\end{tabular}




\begin{tabular}{|c|c|c|c|c|c|c|c|c|c|c|c|c|c|c|c|}
\hline \multirow{3}{*}{\begin{tabular}{|l|}
\multicolumn{1}{|c|}{ Item } \\
9. Stem. Most pupils in our school (Often \\
(O); Sometimes (S); Never (N); Undecided \\
(U)) Steal
\end{tabular}} & \multicolumn{5}{|c|}{ School A (N=50) } & \multicolumn{5}{|c|}{ School B (N=50) } & \multicolumn{5}{|c|}{ Total $(\mathrm{N}=100)$} \\
\hline & 0 & S & & $\mathrm{N}$ & $U$ & $\mathrm{O}$ & $\mathrm{S}$ & & $\mathrm{N}$ & $U$ & 0 & $\mathrm{~S}$ & & $\mathrm{~N}$ & $U$ \\
\hline & $\begin{array}{c}8 \\
(16 \%)\end{array}$ & $\begin{array}{r}22 \\
(440\end{array}$ & & $\begin{array}{l}18 \\
36 \%)\end{array}$ & $2(4 \%)$ & $1(4 \%)$ & $\begin{array}{r}7 \\
(14\end{array}$ & & $\begin{array}{l}37 \\
74 \%\end{array}$ & $\begin{array}{c}5 \\
(10 \%)\end{array}$ & $9(9 \%)$ & $\begin{array}{r}29 \\
(290\end{array}$ & & $\begin{array}{l}55 \\
55 \%)\end{array}$ & $7(7 \%)$ \\
\hline \multirow[b]{2}{*}{$\begin{array}{l}\text { 10. (Often (O); Sometimes (S); Never (N); } \\
\text { Undecided (U)) Fight }\end{array}$} & 0 & $\mathrm{~S}$ & & $\mathrm{~N}$ & $U$ & 0 & 1 & & $\mathrm{~N}$ & $U$ & 0 & & & $\mathrm{~N}$ & $\mathrm{U}$ \\
\hline & $0(0 \%)$ & $\begin{array}{r}10 \\
(20 \%\end{array}$ & & $\begin{array}{l}31 \\
62 \%)\end{array}$ & $\begin{array}{c}9 \\
(18 \%)\end{array}$ & $0(0 \%)$ & $\begin{array}{r}6 \\
(12\end{array}$ & & $\begin{array}{l}42 \\
84 \%\end{array}$ & $2(4 \%$ & $0(0 \%)$ & $(16 \%$ & & $\begin{array}{l}73 \\
73 \%)\end{array}$ & $\begin{array}{c}11 \\
(11 \%)\end{array}$ \\
\hline \multirow[b]{2}{*}{$\begin{array}{l}\text { 11. (Often (O); Sometimes (S); Never (N); } \\
\text { Undecided (U)) Drink Beer }\end{array}$} & 0 & $\mathrm{~S}$ & & $\mathrm{~N}$ & $U$ & 0 & $\mathrm{~S}$ & & $\mathrm{~N}$ & $U$ & 0 & $\mathrm{~S}$ & & $\mathrm{~N}$ & $U$ \\
\hline & $\begin{array}{c}14 \\
(28 \%)\end{array}$ & $\begin{array}{r}27 \\
(540\end{array}$ & & $\begin{array}{c}9 \\
18 \%)\end{array}$ & $0(0 \%)$ & $\begin{array}{c}12 \\
(24 \%)\end{array}$ & $\begin{aligned} 2 \\
(24\end{aligned}$ & & $\begin{array}{c}11 \\
22 \%\end{array}$ & $\begin{array}{c}6 \\
(12 \%)\end{array}$ & $\begin{array}{c}26 \\
(26 \%)\end{array}$ & $\begin{aligned} 48 \\
(480\end{aligned}$ & & $20 \%$ & $6(6 \%)$ \\
\hline \multirow[b]{2}{*}{$\begin{array}{l}\text { 12. (Often (O); Sometimes (S); Never (N); } \\
\text { Undecided (U)) Smoke }\end{array}$} & 0 & $\mathrm{~S}$ & & $\mathrm{~N}$ & $U$ & 0 & $\mathrm{~S}$ & & $\mathrm{~N}$ & U & 0 & $1-1$ & & $\mathrm{~N}$ & $U$ \\
\hline & $3(6 \%)$ & $\begin{array}{r}16 \\
(32\end{array}$ & & $\begin{array}{l}26 \\
52 \%)\end{array}$ & $\begin{array}{c}5 \\
(10 \%)\end{array}$ & $4(8 \%)$ & $\begin{aligned} 15 \\
(30\end{aligned}$ & & $\begin{array}{l}28 \\
56 \%\end{array}$ & $36 \%$ & $7(7 \%)$ & 31 & & $\begin{array}{c}54 \\
54 \%)\end{array}$ & $8(8 \%)$ \\
\hline \multirow{2}{*}{$\begin{array}{l}\text { 13. The moral atmosphere in our school - } \\
\text { (Helps us to learn better (LB) Disturbs our } \\
\text { Learning (DL); Undecided (U)) }\end{array}$} & LB & & $\mathrm{DL}$ & & $U$ & LB & & $\mathrm{DL}$ & & U & LB & & $\mathrm{DL}$ & & U \\
\hline & $17(34$ & & $\begin{array}{c}28 \\
(56 \%) \\
\end{array}$ & & $(10 \%)$ & $24(48$ & & $\begin{array}{r}26 \\
(52 \%) \\
\end{array}$ & & $0(0 \%)$ & $41(41$ & & $\begin{array}{c}54 \\
(54 \%) \\
\end{array}$ & & $5(5 \%)$ \\
\hline \multirow{2}{*}{$\begin{array}{l}\text { 15. The moral atmosphere in our school - } \\
\text { (Is okay as it is (OK); Should improve (SI); } \\
\text { Undecided (U)) }\end{array}$} & OK & & $\mathrm{SI}$ & & $\mathrm{U}$ & $\mathrm{OK}$ & & $\mathrm{SI}$ & & $U$ & $\mathrm{OK}$ & & $\mathrm{SI}$ & & U \\
\hline & $8(16 \%)$ & & $\begin{array}{c}41 \\
(81 \%)\end{array}$ & & $(2 \%)$ & $19(38$ & & $\begin{array}{c}31 \\
62 \%\end{array}$ & & $0(0 \%)$ & $27(27$ & & $\begin{array}{c}72 \\
(72 \%)\end{array}$ & & $1(1 \%)$ \\
\hline
\end{tabular}

Table 1 (b): Pupils' Responses to the School Moral Atmosphere Questionnaire: Yes-No Ratings - $(\mathrm{N}=100)$

\begin{tabular}{|l|c|c|c|c|c|c|}
\hline \multirow{2}{*}{\multicolumn{1}{|c|}{ Item }} & \multicolumn{5}{|c|}{ Responses } \\
\cline { 2 - 6 } & \multicolumn{2}{|c|}{ School A (N=50) } & \multicolumn{2}{c|}{ School B (N=50) } & \multicolumn{2}{c|}{ Total (N=100) } \\
\cline { 2 - 7 } & Yes & No & Yes & No & Yes & No \\
\hline 2. Our school respects the rights of pupils. & $17(34 \%)$ & $33(66 \%)$ & $39(78 \%)$ & $11(22 \%)$ & $56(56 \%)$ & $44(44 \%)$ \\
\hline $\begin{array}{l}\text { 4. Our school head shows good moral } \\
\text { behaviour }\end{array}$ & $38(76 \%)$ & $12(24 \%)$ & $45(90 \%)$ & $5(10 \%)$ & $83(83 \%)$ & $17(17 \%)$ \\
\hline $\begin{array}{l}\text { 5. Teachers in our school show good moral } \\
\text { behaviour. }\end{array}$ & $24(48 \%)$ & $26(52 \%)$ & $29(58 \%)$ & $21(42 \%)$ & $53(53 \%)$ & $47(47 \%)$ \\
\hline $\begin{array}{l}\text { 8. Most pupils in our school tell the truth even in } \\
\text { cases where they may be punished. }\end{array}$ & $23(46 \%)$ & $27(54 \%)$ & $26(52 \%)$ & $24(48 \%)$ & $49(49 \%)$ & $51(51 \%)$ \\
\hline $\begin{array}{l}\text { 14. The moral atmosphere in our school } \\
\text { negatively influences the behaviour of many } \\
\text { pupils. }\end{array}$ & $30(60 \%)$ & $20(40 \%)$ & $17(34 \%)$ & $33(66 \%)$ & $47(47 \%)$ & $53(53 \%)$ \\
\hline $\begin{array}{l}\text { 16. If you were given a chance to choose a } \\
\text { school, would you choose your present school? }\end{array}$ & $15(30 \%)$ & $35(70 \%)$ & $41(82 \%)$ & $9(18 \%)$ & $56(56 \%)$ & $44(44 \%)$ \\
\hline
\end{tabular}

\section{Data Analysis and Discussion}

In Table 1 (a) Item 1, responses from School A indicate that $48 \%$ of the participants perceived the moral atmosphere in their school as good while $52 \%$ perceive it as poor. These resultS contrast results observed in School B where $82 \%$ of the participants felt that the moral atmosphere in their school was good while only $18 \%$ felt that it was poor. Clearly there are differences in moral atmosphere between the two schools, with School A having a lower level of perceived moral atmosphere than School B. In School B, the majority of pupils (82\%) reported a positive moral atmosphere in the school.

In School A where most pupils (52\%) had a negative perception of their school's moral atmosphere, the study's results also report more norm transgressive behaviour by pupils such as lying (item 8), stealing (item 9), fighting (item 10), drinking beer (item11) and smoking (item 12) than in School B. These observations are in keeping with some of the findings of earlier researchers in this field. For example, Brugman et al. (2003) found that the perception of moral atmosphere was a better predictor of norm transgressive behaviour. In their study among some Russian schools, they found out that pupil misbehaviour was high in schools with low perceived moral atmosphere.

Results from item 14 also confirm the fact that a school's moral atmosphere can either negatively or positively affect pupils' behaviour. In item 14,60\% of the pupils from School A said that the moral atmosphere in their school has negatively affected most pupils' behaviour while only $34 \%$ of pupils in School B reported similar effects.

Although school life remained relatively normal in the two schools, many pupils felt that despite the fact that heads in the two school were exemplary (item 4), most teachers were not (item 5). Interview data as well as reasons given by 
many pupils on the questionnaire, report sexual, physical (beating) and psychological (scolding) abuse of pupils by many teachers. Responses to item 2 indicate that $60 \%$ of the pupils in School A felt that their school does not respect the rights of pupils. This may specifically refer to teachers since heads in the two schools were reported exemplary. If these observations are accepted, then the results of this study can be extrapolated to mean that the moral atmosphere in many of our schools is lower than pupils expect. How then do we expect a crab to teach its young ones to walk straight when it cannot walk straight itself?

Interview data indicate that the moral atmosphere currently obtaining in some schools in Zimbabwe does not bode well not only for the proper socialisation of children, but it also results in many pupils feeling unsafe and threatened in their own school (item 3). To the present writer, what many teachers do not seem to realise is that schools are places where many children do not like to be since they are like prisons that take away people's freedom. To further instil fear in these children who already do not like school only exacerbates the situation.

Some pupils reported that some teachers beat them and scold them in front of others yet they are mature. This greatly humiliates them. There were also great concerns about sexual abuse of pupils in the two schools. One pupil interviewee angrily said,

How do you expect us to pass in such threatening environments? What moral values do we learn from such abusive schools? School heads and Ministry officials have often received reports of the abuses but they ignore them in order to protect their own positions.

The sentiments expressed above suggest that many pupils no longer trust schools. This position is corroborated by responses to item 13 which indicate that the majority of pupils (54\%) from the two schools felt that the moral atmosphere in their schools disturbs their learning. There is also a cry from pupils in both schools (School A: 82\%; School B: 72\%) for the moral atmosphere in their schools to improve (item 15).

Although pupils in School B generally portray a more positive school moral atmosphere than those in School A, and although the majority of pupils (82\%) in School B would prefer their current school to another one (item 16), they still think that the moral atmosphere in their school could be better. This seems to be an acknowledgement that, first, pupils are aware of the impact of a school's moral atmosphere on their school life and, second, in many of the pupils' views, some schools fall short as regards the kind of moral atmosphere that prevails in them.

What is discussed above may be the reason why, overall, $52 \%$ of all the participants from the two schools (item 6 ) said that they learn better moral values from home than from school. It was on this issue that there was almost unanimity of opinion among the majority of pupils from School A (54\%) and from School B (50\%). Informal discussions with some of the teachers indicated that most teachers think that the teaching of moral and social responsibility of children rests with parents, not with the school. One of the teachers commented,

The mistake society makes is to think that schools will provide for all the socialisation and disciplinary needs of children yet, as schools, we do not have the capacity, time or motivation to do that. Our focus is on examinations.

Such a comment may suggest that the values that the Zimbabwean education must promote have not been adequately identified, or at least, clearly articulated. Is it an education for life or for passing examinations?

Perhaps our education system lays too much emphasis on examinations and certificates, forcing teachers to ignore the important task of teaching children the necessary social and life skills. In the present writer's view, it is usually such ill-socialised children who often turn schools into battle fields as evidenced by the reported fights in the two schools (item 10). In School A which was perceived to have a lower school moral atmosphere, the majority of pupils (66\%) indicated that most pupils in that school only behave well in the presence of teachers. In School B, which was perceived to have a higher school moral atmosphere, $44 \%$ of the pupils also indicated that most pupils in their school only behave well in the presence of teachers. These observations suggest that some pupils in some Zimbabwean secondary schools may be lacking self-discipline.

A school where pupils lack self-discipline and where pupils are generally dissatisfied with what is going on in the school little functions as a harmonious community. Relations tend to be poor and usually there is very little if any, commitment to the school's goals. Pupils in such a school may also little identify themselves with the school. Once pupils adopt such attitudes, misbehaviour that may involve the destruction of school property may result. In fact, Brugman et al. (2003) found that pupils who reported little connectedness with their school had higher rates of offences than those who reported connectedness with their school. This shows the need for schools to establish a school moral atmosphere which makes pupils feel belonging to and owning the school because such pupils have been found to be committed to the school goals and to act responsibly (Solomon et al., 1996). 


\section{Conclusion}

The results of this study show a relatively low moral atmosphere and moral cohesion in the two schools studied, but more so in School A than in School B. Pupils from both schools generally reported dissatisfaction with the existing moral atmosphere in their schools, and called for the sanitisation of school environments. The moral atmosphere was seen as lacking good models and therefore breading delinquent children. It was also seen as humiliating to many pupils, disturbing pupils' learning and causing lack of commitment to the school and to school life.

In all, the results of this study suggest that the moral atmosphere of a school as measured by the behaviour of all members of the school community is critical for the effective functioning of the school. For Solomon et al. (1996), a school with a good moral atmosphere is where all members respect the rights of others, care about and support each other, have a sense of shared purpose and are committed to the goals of the school. To the present writer, unless our schools function as intended and mandated, many parents and children will lose confidence in the schooling system, resulting in lack of commitment to education.

\section{Recommendations}

- The results of this study have pointed to the need for heads of schools and ministry officials to ensure that the moral atmosphere in schools in supportive of pupils' learning. There may be need for more adequate and effective legislation not only for protecting pupils but also for ensuring that pupils do not abuse the protection they get from legislation.

- A larger study involving different types of schools (rural, urban, church etc) to see if the results of the present study can be confirmed and extended is perhaps necessary.

\section{References}

Brugman, D.; Podolskij, A. I.; Hlymans, P. G.; Boom, J.; Karabanova, O. \& Idobaeva, O. (2003). Perception of moral atmosphere in school and norm transgressive behaviour in adolescents: An intervention study. International Journal of Behavioural Development, 27(4) 289-300.

Brugman.; Tavecchio, L. W. C.; Van Os, B. J. \& Host, K. (1999). Students' perception of moral atmosphere in secondary schools, MOSAIC Monographs. No. 8. Bath: University of Bath Press.

Fishbein, M. (1975). Beliefs, Attitudes, Intention and Behaviour. Philippines: Addison Wesley.

Gielen, U. (1991). Research on moral reasoning. In L. Kuhmerker (Ed). The Kohlberg Legacy for the Helping Professions. Birmingham: Al Doxa.

Host, K.; Brugman, D.; Tavecchio, L. W. C. \& Beem, A. L. (1998). Students' perception of the moral atmosphere in secondary schools and the relationship between moral competence and moral atmosphere. Journal of Moral Education, 27,47 - 70.

Kelderman, H. (1986). Common Item Equating with the Log-Linear Rasch Model. Twentye: University of Twentyre.

Kuther, T. L. (2000). Moral reasoning, perceived competence and adolescent engagement in risk activity. Journal of Adolescent, 23, 599-604.

Mushoriwa, T. D. (2008). Secondary school pupils' perceptions of sexual harassment by peers. The Nigerian Journal of Guidance and Counselling: . 13 (1) 180-189.

Power, C.; Higgins, A. \& Kohlberg, L. (1989). Lawrence Kohlberg's Approach to Moral Education. New York: Columbia.

Rajecki, D. W. (1982). Attitudes: Themes and Advances. Massachussetts: Sinaner.

Rest, J. R.; Narvaez, D.; Bebeau, M. J. \& Thoma, S. J. (1999). Post-Conventional Moral Thinking. New Jersey: Erlbaun.

Solomon, D.; Watson, M.; Battistich, V.; Schaps, E. \& Delucchi, K. (1996). Creating classrooms that students experience as communities. American Journal of Community Psychology, 24, 719-728.

Van Dalen, D. B. (1979). Understanding Educational Research: An Introduction. New York: McGraw-Hill. 